\title{
HPLC method development and validation for the estimation of axitinib in rabbit plasma
}

\author{
Achanta Suneetha ${ }^{1 *}$, Sharmila Donepudi² \\ ${ }^{1}$ Department of Pharmaceutical Analysis, Hindu College of Pharmacy, Andhra Pradesh, India, ${ }^{2}$ Department of Pharmaceutical \\ Analysis, V.V. Institute of Pharmaceutical Sciences, Andhra Pradesh, India
}

\begin{abstract}
A rapid, sensitive, and accurate high performance liquid chromatography for the determination of axitinib (AN) in rabbit plasma is developed using crizotinibe as an internal standard (IS). Axitinib is a tyrosine kinase inhibitor, used in the treatment of advanced kidney cancer, which works by slowing or stopping the growth of cancer cells. The chromatographic separation was performed on a Waters 2695, Kromosil $(150 \mathrm{~mm} \times 4.6 \mathrm{~mm}, 5 \mu \mathrm{m})$ column using a mobile phase containing buffer $(\mathrm{pH} 4.6)$ and acetonitrile in the ratio of $65: 35 \mathrm{v} / \mathrm{v}$ with a flow rate of $1 \mathrm{~mL} / \mathrm{min}$. The analyte and internal standard were extracted using liquid-liquid extraction with acetonitrile. The elution was detected by photo diode array detector at 320 $\mathrm{nm}$. The total chromatographic runtime is $10.0 \mathrm{~min}$ with a retention time for axitinib and IS of 5.685, and $3.606 \mathrm{~min}$, respectively. The method was validated over a dynamic linear range of $0.002-0.2 \mu \mathrm{g} / \mathrm{mL}$ for axitinib with a correlation coefficient of $\mathrm{r}^{2} 0.999$.
\end{abstract}

Keywords: High performance liquid chromatography/method validation. Axitinib/determination. Axitinib/ kidney cancer treatment. Crizotinibe. Rabbit plasma. Tyrosine kinase inhibitor.

\section{INTRODUCTION}

Axitinib is an oral, potent, and selective inhibitor of vascular endothelial growth factor receptors (VEGFR) 1 , 2, and 3 (Cohenet al., 2008). Axitinib is marketed under the name Inlyta (2014), and if one previous systemic therapy for kidney cell cancer has failed, axitinib is indicated (leaflet (Pfizer) revised 8/2014). IUPAC name was ( $N$-methyl-2-[[3-[(E)-2-pyridin-2-yl-ethenyl]-1Hindazol-6-yl]sulfanyl]benzamide). It is soluble in DMSO $\left(42 \mathrm{mg} / \mathrm{mL}\right.$ at $\left.25^{\circ} \mathrm{C}\right)$, water $\left(<1 \mathrm{mg} / \mathrm{mL}\right.$ at $\left.25^{\circ} \mathrm{C}\right)$, ethanol $\left(<1 \mathrm{mg} / \mathrm{mL}\right.$ at $\left.25^{\circ} \mathrm{C}\right)$, methanol, and DMF $(\sim 0.25 \mathrm{mg} / \mathrm{mL})$ (NCBI Compound Database, 2016). Axitinib prevents the progression of cancer by inhibiting angiogenesis and blocking tumor growth (Van Geel, Beijnen, Shellens et al., 2012). The chemical structure of axitinib is given in Figure1.

Crizotinibe is a tyrosine kinase receptor inhibitor (Wani et al.,2014). More specifically, it inhibits anaplastic lymphoma kinase (ALK), hepatocyte growth factor receptor (HGFR, c-MET), and Recepteur d'Origine

\footnotetext{
*Correspondance: A. Suneetha. Department of Pharmaceutical Analysis. Hindu College of Pharmacy, Amaravathi Road, Guntur-522 002 - Andhra Pradesh, India. E-mail:drasuneetha@gmail.com
}

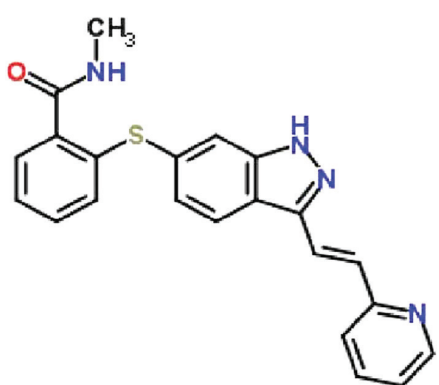

FIGURE 1 - Structure of axitinib.

Nantais (RON). Abnormalities in the ALK gene caused by mutations or translocations may lead to the expression of oncogenic fusion proteins. In patients with NSCLC, they have the EML4-ALK gene. Crizotinibe inhibits ALK tyrosine kinase, which ultimately results in the decreased proliferation of cells that carry the genetic mutation and tumor survivability (Wani et al., 2014; Probhash et al., 2013).

The literature survey revealed very few analytical methods for the estimation of axitinib (Sagar, Bera, Panda et al., 2016; Sarada, Reddy, 2016), which included estimation in biological fluids (Garrettet al., 2014). The available methods include LC-MS (Sparidans et al., 2009) ion mobility spectrometry and DART mass spectrometry 
(Likar et al., 2011). The present work emphasizes the development of a rapid, economical and simple method, which utilizes protein precipitation for sample preparation and HPLC using UV detection for the quantification of axitinib in rabbit plasma.

\section{EXPERIMENTAL}

\section{Chemicals and reagents}

The pure samples of axitinib and crizotinibe were obtained from Sigma-Aldrich. HPLC grade Acetonitrile, HPLC grade Methanol and all other chemicals were obtained from Merck chemical division, Mumbai. HPLC grade water obtained from a Milli-Q water purification system was used throughout the study. Rabbit plasma was purchased from albino labs, Miyapur, Hyderabad.

\section{Instrumentation}

Chromatography was performed with the waters 2695 HPLC system provided with a high speed autosampler, column oven, degasser and 2996 PDA detector to provide a compact process and with class Empower-2 software.

\section{Chromatographic method}

The separation was carried on a Kromosil C18 analytical column $(150 \mathrm{~mm} \times 4.6 \mathrm{~mm} \times 5 \mu \mathrm{m})$ using the mobile phase containing buffer and acetonitrile in the ratio of $65: 35 \% \mathrm{v} / \mathrm{v}$; this was delivered isocratically at a flow rate of $1 \mathrm{~mL} / \mathrm{min}$. The injection volume was 10 $\mu \mathrm{L}$ and the run time was $10 \mathrm{~min}$. The temperatures of the column and autosampler were maintained at $30^{\circ} \mathrm{C}$ and $5{ }^{\circ} \mathrm{C}$, respectively. The detection was performed at a wavelength of $320 \mathrm{~nm}$.

\section{Buffer preparation}

One $\mathrm{mL}$ of perchloric acid was transferred into a $1000 \mathrm{~mL}$ volumetric flask and made up to $1000 \mathrm{~mL}$ with water; $\mathrm{pH}$ was adjusted to 4.6 using triethylamine.

\section{Preparation of standard solutions}

The standard stock solution of axitinib was prepared at $0.1 \mathrm{mg} / \mathrm{mL}$ with the diluent composition of water:acetonitrile $50: 50 \% \mathrm{v} / \mathrm{v}$. Axitinib spiking solutions $(0.46 \mu \mathrm{g} / \mathrm{mL}$ to $46 \mu \mathrm{g} / \mathrm{mL})$ were prepared from stock solution. Calibration standards were prepared by spiking stock solution into blank plasma to obtain $0.002,0.004$, $0.02,0.04,0.08,0.1,0.15$ and $0.2 \mu \mathrm{g} / \mathrm{mL}$.

\section{Sample preparation}

To $250 \mu$ Lof drug free plasma, $50 \mu \mathrm{L}$ of internal standard and $10 \mu \mathrm{L}$ of axitinib was spiked and $2 \mathrm{~mL}$ of acetonitrile was added. The above mixture was subjected to the cyclomixer for $15 \mathrm{~s}$, vortexed for $2 \mathrm{~min}$ and finally centrifuged for $3 \mathrm{~min}$ at $3200 \mathrm{rpm}$. After centrifugation, the organic layer was collected and $10 \mu \mathrm{L}$ was directly injected into HPLC.

\section{Method validation}

A thorough and complete method of validation was performed following the USFDA guidelines. The method was validated for system suitability, autosampler carryover, specificity and screening of the biological matrix, sensitivity, matrix effect, linearity, precision and accuracy, recovery of analyte and internal standard, ruggedness on precision accuracy and linearity (Maring et al., 2005; Rote et al., 2013; Phatak, Vaidya, Phatak, 2014), reinjection reproducibility and stability on day zero, long batch, LT at $-28^{\circ} \mathrm{C}$ and LT at $-80^{\circ} \mathrm{C}$.

System suitability was assessed by a middle quality control (MQC) sample at a concentration of $0.08 \mu \mathrm{g} / \mathrm{mL}$, with six homogenous injections; relative standard deviation (\%RSD) values for retention time and response of the analyte and internal standard were calculated. Autosample carryover was assessed by injecting a sequence of standard blank, an upper limit of quantification (ULOQ) concentration of $0.2 \mu \mathrm{g} / \mathrm{mL}$ and a lower limit of quantification (LLOQ) concentration of $0.002 \mu \mathrm{g} / \mathrm{mL}$.

Specificity and screening of the biological matrix was assessed using six blank standards and LLOQ level samples. All samples were checked for any interference of blank and sample response. Sensitivity was assessed by LLOQ level sample to determine the lowest limit of detection and the $\%$ mean accuracy and $\% \mathrm{CV}$ (coefficient of variation) were calculated. Matrix effect on analyte quantitation with respect to consistency in signal (suppression/enhancement) was checked in six different lots of axitinib plasma; three replicates, at LQC and HQC levels, were prepared from these plasma samples (total 36 QC samples) and assessed for accuracy in terms of $\%$ bias in all of the QC samples.

Linearity of the method was determined by analysis of standard plots associated with an 8-point standard calibration curve. The calibration curve was found be 
linear over the range of $0.002-0.2 \mu \mathrm{g} / \mathrm{mL}$. Intra-batch and inter-batch accuracy and precision were evaluated at four different concentrations levels (LLOQ, LQC, MQC and HQC) in six replicates for both analytes. Mean values were obtained for calculated drug concentrations over these batches. The accuracy and precision were calculated and expressed in terms of \% accuracy and coefficient of variation $(\% \mathrm{CV})$, respectively.

Recovery of the analytes from the extraction procedure was performed at LQC, MQC, and HQC levels. It was evaluated by comparing the peak area of the extracted samples (spiked before extraction) to the peak area of unextracted samples (quality control working solutions spiked in extracted plasma). Ruggedness of the method was assessed by using different analysts for linearity, precision and accuracy in the levels of ULOQ, LQC, MQC and HQC.

Stability studies were performed at Zero hours, Long batch, LT at $-28{ }^{\circ} \mathrm{C}$ and LT at $-80{ }^{\circ} \mathrm{C}$. Day zero had two samples with six replicates of HQC and LQC levels. Long batch had 35 replicates of LLOQ, LQC, MQC and HQC level of samples with $\%$ Mean accuracy. LT at $-28^{\circ} \mathrm{C}$ and LT at $-80{ }^{\circ} \mathrm{C}$ had HQC and LQC levels with \% stability findings by comparing stability sample with freshly spiked samples.

\section{RESULTS AND DISCUSSIONS}

The chromatographic separation of axitinib using crizotinibe was optimized after several trials using the $\mathrm{C} 18$ column mobile phase with different ratios of perchloric acid buffer and acetonitrile at various $\mathrm{pH}$. The best results were achieved by using perchloric acid buffer ( $\mathrm{pH} 4.6$ adjusted by using triethyl amine) and acetonitrile in the ratio of $65: 35 \mathrm{v} / \mathrm{v}$. Good sensitivity was obtained at a wavelength of $320 \mathrm{~nm}$. The best separation was achieved with a flow rate of $1 \mathrm{~mL} / \mathrm{min}$. The analyte and internal standard were eluted at 5.685, and $3.606 \mathrm{~min}$, respectively.

\section{System suitability and auto sampler carryover}

Six replicate samples of middle quality control samples at different concentrations were injected along with internal standards and \% CV was calculated. The $\% \mathrm{CV}$ of the retention time of analyte and IS was found to be $\leq 2.00 \%$. The $\% \mathrm{CV}$ of the peak area ratio of analyte to IS was found to be $\leq 5.00 \%$. The results were found to be within the limits and are summarized in Table I.

The carryover experiment was performed to ensure that it does not affect the accuracy and precision. There was no carryover observed. The results were presented in Table II.

\section{Specificity and screening of biological matrix}

The response of interfering peaks in the standard blank at the retention time of analyte should be $\leq 20.00 \%$ of that in LLOQ. The response of interfering peaks in the standard blank at the retention time of IS should be $\leq 5.00 \%$ of that in LLOQ. All of the samples were found to be free of interference at retention time of the analyte in blank samples. The results are shown in Table III. This shows the specificity of the method towards axitinib by the absence of interfering peaks.

\section{Sensitivity}

The accuracy and precision of axitinib at LLOQ level was found to be $6.50 \% \mathrm{CV}$ and \% mean accuracy was found to be $107.31 \%$. Acceptance criteria state that at

TABLE I - System suitability data

\begin{tabular}{|c|c|c|c|c|c|}
\hline \multirow{2}{*}{ Sample Name } & \multicolumn{2}{|c|}{ Analyte } & \multicolumn{2}{|c|}{ IS } & \multirow{2}{*}{ Area Ratio } \\
\hline & Area & Rt (min) & Area & Rt (min) & \\
\hline \multirow[t]{6}{*}{ MQC } & 24515 & 5.63 & 26987 & 3.61 & 0.9084 \\
\hline & 24698 & 5.63 & 27012 & 3.61 & 0.9143 \\
\hline & 25156 & 5.68 & 26358 & 3.62 & 0.9544 \\
\hline & 24956 & 5.63 & 27114 & 3.62 & 0.9204 \\
\hline & 24658 & 5.62 & 26874 & 3.62 & 0.9175 \\
\hline & 25012 & 5.63 & 26914 & 3.61 & 0.9293 \\
\hline MEAN & & 5.635 & & 3.615 & 0.92407 \\
\hline $\mathrm{SD}$ & & 0.0200 & & 0.0059 & 0.016394 \\
\hline$\% \mathrm{CV}$ & & 0.35 & & 0.16 & 1.77 \\
\hline
\end{tabular}


TABLE II - Auto sampler carryover

\begin{tabular}{|c|c|c|c|c|}
\hline \multirow{2}{*}{ Sample ID } & \multicolumn{2}{|c|}{ Peak Area } & \multicolumn{2}{|c|}{$\%$ Carryover } \\
\hline & Drug & IS & Drug & IS \\
\hline \multicolumn{5}{|c|}{ Unextracted samples } \\
\hline RS & 0 & 0 & N/A & N/A \\
\hline AQ ULOQ & 65214 & 48695 & 0.00 & 0.00 \\
\hline RS & 0 & 0 & & \\
\hline AQ LLOQ & 945 & 48125 & N/A & N/A \\
\hline \multicolumn{5}{|c|}{ Extracted samples } \\
\hline STD Blk & 0 & 0 & N/A & N/A \\
\hline ULOQ & 47937 & 26914 & 0.00 & 0.00 \\
\hline STD Blk & 0 & 0 & & \\
\hline LLOQ & 457 & 26978 & N/A & N/A \\
\hline
\end{tabular}

TABLE III - Specificity and screening of biological matrix

\begin{tabular}{|c|c|c|c|c|c|}
\hline \multirow{2}{*}{ Sample } & \multicolumn{2}{|c|}{ Response } & \multicolumn{2}{|c|}{$\%$ Interference } & \multirow{2}{*}{ Pass/Fail } \\
\hline & Drug & IS & Drug & IS & \\
\hline STD Blk1 & 0 & 0 & 0.00 & 0.00 & Pass \\
\hline LLOQ1 & 450 & 26359 & & & \\
\hline STD Blk2 & 0 & 0 & 0.00 & 0.00 & Pass \\
\hline LLOQ2 & 498 & 26478 & & & \\
\hline STD Blk3 & 0 & 0 & 0.00 & 0.00 & Pass \\
\hline LLOQ3 & 512 & 26921 & & & \\
\hline STD Blk4 & 0 & 0 & 0.00 & 0.00 & Pass \\
\hline LLOQ4 & 465 & 25986 & & & \\
\hline STD Blk5 & 0 & 0 & 0.00 & 0.00 & Pass \\
\hline LLOQ5 & 497 & 26519 & & & \\
\hline STD Blk6 & 0 & 0 & 0.00 & 0.00 & Pass \\
\hline LLOQ6 & 491 & 26189 & & & \\
\hline
\end{tabular}

least $67 \%$ (4 out of 6 ) of samples should be within 80.00 $120.00 \%$. \% Mean accuracy should be within the range $80.00-120.00 \%$. \% CV accuracy should be $\leq 20.00 \%$. The results meet the acceptance limit and are shown in Table IV. This confirms that the method is highly sensitive for axitinib.

\section{Matrix effect}

The matrix effect data of HQC and LQC are presented in Table $\mathrm{V}$. The acceptance criteria state that at least $67 \%$ ( 2 out of 3 ) of samples at each level should be within the range $85.00-115.00 \%$. At least $80 \%$ ( 5 out of 6 ) of the matrix lot should be within the acceptance criteria. The $\%$ mean accuracy of back calculated concentration of
LQC and HQC samples prepared from different biological matrix lots should be within the range $85.00-115.00 \%$.

\section{Linearity}

The linearity of the method was evaluated at eight concentration levels including the LLOQ. The calibration curve was found to be linear in the range $0.002-0.2 \mu \mathrm{g} /$ $\mathrm{mL}$, with a correlation coefficient $\left(\mathrm{r}^{2}\right)$ of 0.999 . The calibration curves were defined in three runs based on triplicate assays of the spiked blank plasma samples. The linear graph is shown in Figure 2. Each back-calculated standard concentration was within the acceptance limits. The data of calculated calibration standards are presented in Table VI. 
TABLE IV - Sensitivity data

\begin{tabular}{lc}
\hline Sample & LLOQ \\
\cline { 2 - 2 } & \multicolumn{2}{c}{ Nominal Concentration $(\mu \mathrm{g} / \mathrm{mL})$} \\
\cline { 2 - 2 } & \multicolumn{2}{c}{ Calculated Concentration $(\mu \mathrm{g} / \mathrm{mL})$} \\
\hline 1 & 0.0021 \\
2 & 0.0021 \\
3 & 0.0020 \\
4 & 0.0020 \\
5 & 0.0023 \\
6 & 0.0023 \\
\hline $\mathrm{N}$ & 6 \\
Mean & 0.0021 \\
SD & 0.00014 \\
\% CV & $\mathbf{6 . 4 4}$ \\
\% Mean Accuracy & $\mathbf{1 0 7 . 3 1}$ \\
\hline
\end{tabular}

\section{Precision}

The inter-day and intraday precisions were measured as relative standard deviations and expressed as percentages of the concentration (Alanazi et al., 2012) of Axitinib. The $\% \mathrm{CV}$ of estimated concentrations for all four quality control samples with six replicates for analyte was within the range $6.54-11.68 \%$. The $\%$ mean accuracy
Area response ratio

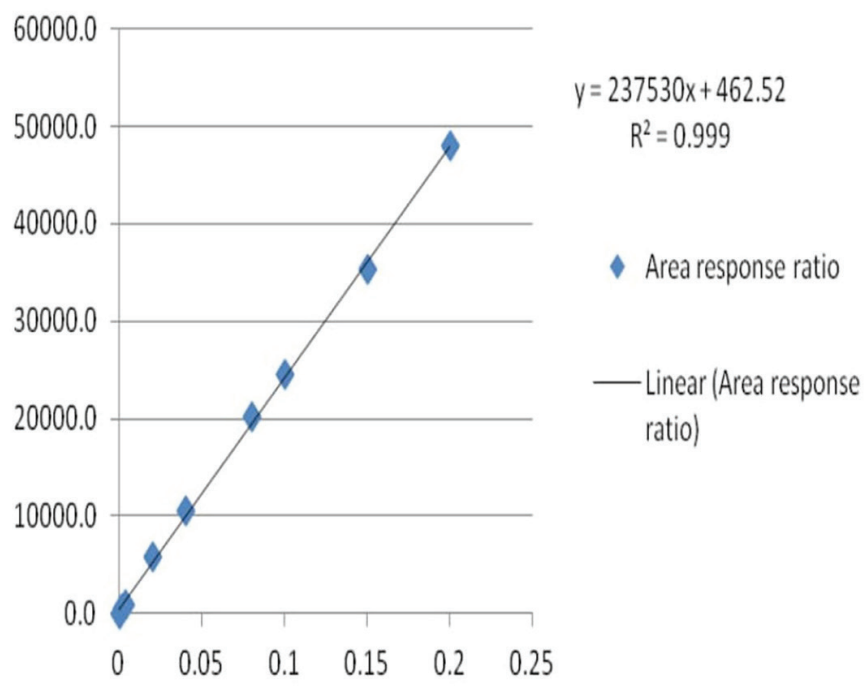

FIGURE 2 - Calibration plot for concentration v/s area ratio.

for LLOQ, LOQ, MOQ and HQC was within the range $95.06-107.71 \%$. For inter-day precision and accuracy, the $\% \mathrm{CV}$ and accuracy results of all quality control samples were within the ranges 7.49-8.95\% and 98.51-104.84\%, respectively. The acceptance criterion states that at least $67 \%$ of the QC samples should be $\leq 15.00 \%$ and for the LLOQ should be $\leq 20.00 \%$. \% Mean accuracy for LQC, MQC and HQC samples should be within the range 85.00-

TABLE V - Matrix effect

\begin{tabular}{|c|c|c|c|}
\hline \multirow[t]{6}{*}{ S. No. } & \multirow[t]{6}{*}{ Plasma Lot No. } & HQC & LQC \\
\hline & & \multicolumn{2}{|c|}{ Nominal Concentration $(\mu \mathrm{g} / \mathrm{mL})$} \\
\hline & & 0.150 & 0.020 \\
\hline & & \multicolumn{2}{|c|}{ Nominal Concentration Range $(\mu \mathrm{g} / \mathrm{mL})$} \\
\hline & & $(0.128-0.173)$ & $(0.017-0.023)$ \\
\hline & & \multicolumn{2}{|c|}{ Calculated Concentration $(\mathrm{ng} / \mathrm{mL})(\mathrm{n}=3)$} \\
\hline 1 & LOT1 & 0.137 & 0.019 \\
\hline 2 & LOT2 & 0.155 & 0.021 \\
\hline 3 & LOT3 & 0.170 & 0.021 \\
\hline 4 & LOT4 & 0.144 & 0.018 \\
\hline 5 & LOT5 & 0.162 & 0.022 \\
\hline 6 & LOT6 & 0.163 & 0.020 \\
\hline \multicolumn{2}{|c|}{ Mean } & 0.1551 & 0.0201 \\
\hline \multicolumn{2}{|c|}{ SD } & 0.01386 & 0.00160 \\
\hline \multicolumn{2}{|c|}{$\% \mathrm{CV}$} & 8.94 & 7.98 \\
\hline \multicolumn{2}{|c|}{$\%$ Mean Accuracy } & 103.41 & 100.56 \\
\hline \multicolumn{2}{|c|}{ No. of QC Failed } & 0 & 0 \\
\hline
\end{tabular}


$115.00 \%$ and for the LLOQ sample should be within the range $80.00-120.00 \%$. The data for precision and accuracy are given in Table VII. The chromatogram of quality control samples is shown in Figures 3-7. The data obtained indicate an acceptable precision for all concentrations assayed for both intraday and inter-day samples.

\section{Recovery of analyte}

Recovery is the detector response obtained from an amount of analyte added to and extracted from the biological matrix (FDA, 2001). The extraction recovery of axitinib at HQC, MQC and LQC was found to be 50.45,

TABLE VI - Linearity

\begin{tabular}{lccccccc}
\hline \multirow{2}{*}{ S. No. } & $\begin{array}{c}\text { Conc. } \\
(\mu \mathrm{g} / \mathrm{mL})\end{array}$ & \multicolumn{2}{c}{ Back Calculated Concentration $(\mu \mathrm{g} / \mathrm{mL})$} & & Avg. & \%CV & $\begin{array}{c}\text { \% Mean } \\
\text { Accuracy }\end{array}$ \\
\cline { 2 - 5 } 1 & 0.002 & 0.002 & 0.002 & 0.002 & 0.002 & 2.13 & 107.50 \\
2 & 0.004 & 0.004 & 0.004 & 0.005 & 0.004 & 13.05 & 98.33 \\
3 & 0.020 & 0.018 & 0.019 & 0.018 & 0.018 & 3.15 & 91.67 \\
4 & 0.040 & 0.039 & 0.041 & 0.042 & 0.040 & 3.89 & 101.58 \\
5 & 0.080 & 0.076 & 0.082 & 0.088 & 0.082 & 7.47 & 102.21 \\
6 & 0.100 & 0.098 & 0.112 & 0.102 & 0.104 & 6.89 & 104.03 \\
7 & 0.150 & 0.145 & 0.166 & 0.143 & 0.151 & 8.42 & 100.89 \\
8 & 0.200 & 0.185 & 0.228 & 0.214 & 0.209 & 10.49 & 104.50 \\
\hline
\end{tabular}

TABLE VII - Precision interday and intraday data

\begin{tabular}{|c|c|c|c|c|}
\hline & HQC & MQC & LQC & LLOQ \\
\hline & \multicolumn{4}{|c|}{ Nominal Concentration $(\mu \mathrm{g} / \mathrm{mL})$} \\
\hline & 0.150 & 0.080 & 0.020 & 0.002 \\
\hline \multicolumn{5}{|c|}{ Day $1(n=6)$} \\
\hline Mean & 0.1582 & 0.0804 & 0.0196 & 0.0022 \\
\hline SD & 0.01383 & 0.00849 & 0.00128 & 0.00016 \\
\hline$\% \mathrm{CV}$ & 8.75 & 10.56 & 6.54 & 7.59 \\
\hline$\%$ Mean Accuracy & 105.44 & 100.54 & 98.08 & 107.71 \\
\hline \multicolumn{5}{|c|}{ Day-2 $(n=6)$} \\
\hline Mean & 0.1550 & 0.0761 & 0.0202 & 0.0021 \\
\hline $\mathrm{SD}$ & 0.01389 & 0.00610 & 0.00236 & 0.00014 \\
\hline$\% \mathrm{CV}$ & 8.96 & 8.02 & 11.68 & 6.80 \\
\hline$\%$ Mean Accuracy & 103.30 & 95.06 & 101.04 & 105.33 \\
\hline \multicolumn{5}{|c|}{ Day-3 $(n=6)$} \\
\hline Mean & 0.1587 & 0.0799 & 0.0210 & 0.0020 \\
\hline SD & 0.00882 & 0.00678 & 0.00163 & 0.00022 \\
\hline$\% \mathrm{CV}$ & 5.56 & 8.48 & 7.76 & 11.05 \\
\hline$\%$ Mean Accuracy & 105.78 & 99.93 & 105.04 & 101.45 \\
\hline \multicolumn{5}{|c|}{ Between Batch Precision and Accuracy } \\
\hline $\mathrm{N}$ & 18 & 18 & 18 & 18 \\
\hline Mean & 0.1573 & 0.0788 & 0.0203 & 0.0021 \\
\hline SD & 0.01178 & 0.00705 & 0.00180 & 0.00018 \\
\hline$\% \mathrm{CV}$ & 7.49 & 8.95 & 8.89 & 8.47 \\
\hline$\%$ Mean Accuracy & 104.84 & 98.51 & 101.39 & 104.83 \\
\hline
\end{tabular}




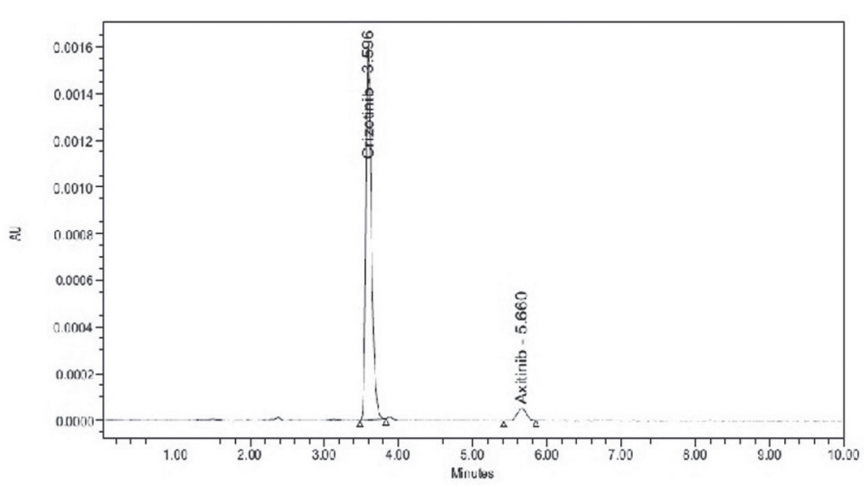

FIGURE 3 - Chromatogram of LLOQ.

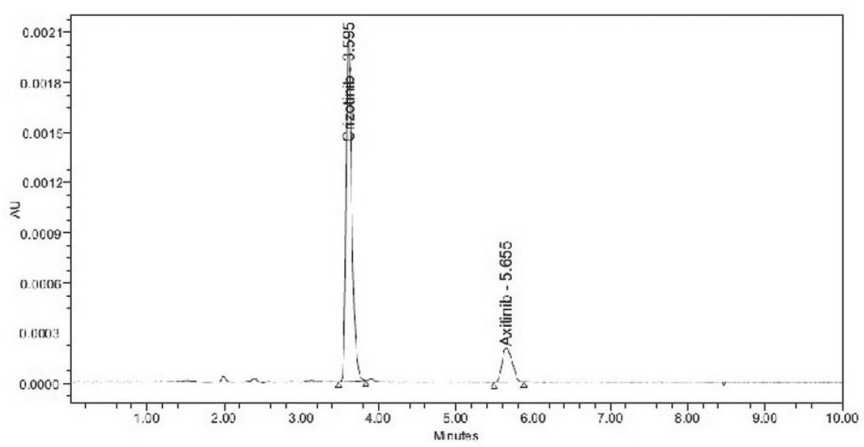

FIGURE 4 - Chromatogram of LQC.

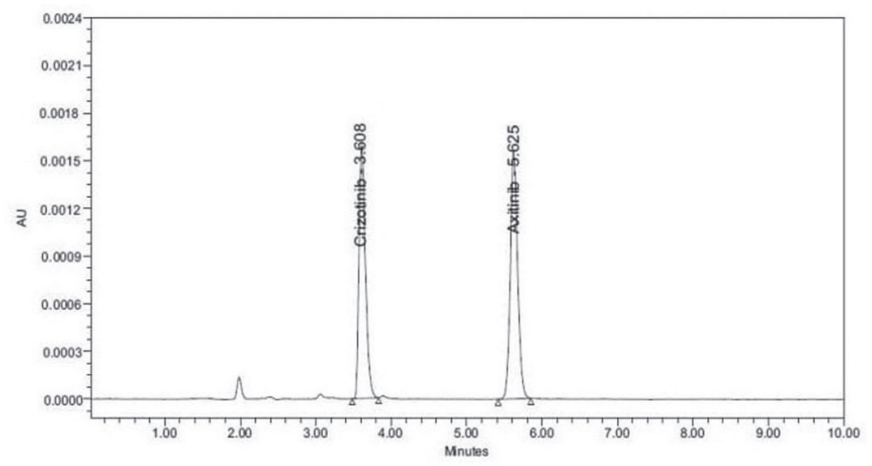

FIGURE 5 - Chromatogram of MQC.

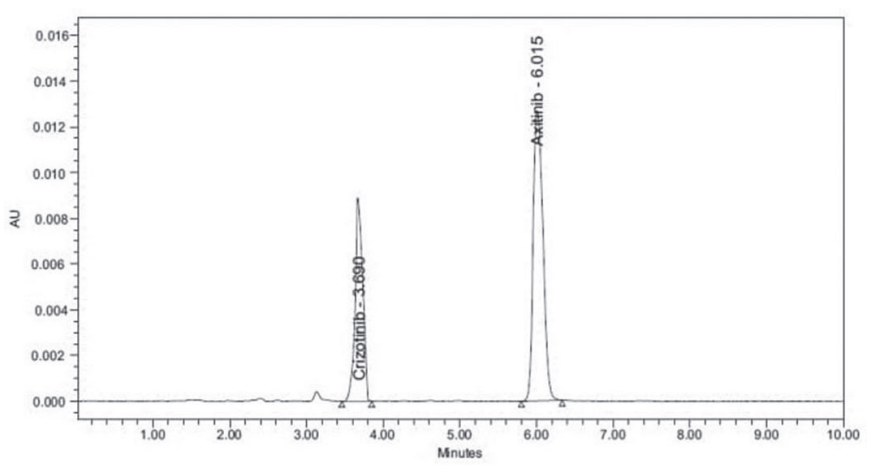

FIGURE 6 - Chromatogram of HQC.

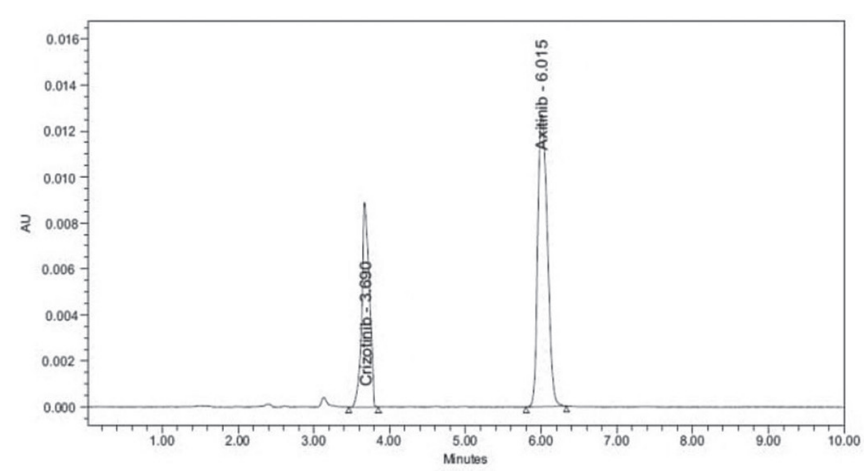

FIGURE 7 - Chromatogram of ULOQ.

57.40 and 58.21, respectively, and that of the internal standard was 74.76. This indicates that the results are coherent. The results of the recovery study are given in Tables VIII and IX. The results are within the acceptance limit. The acceptable limit was $\% \mathrm{CV}$ of recovery at each QC level and IS of $\leq 15.00 \%$. The overall mean recovery $\%$ CV for all QC levels should be $\leq 20.00 \%$.

\section{Ruggedness}

The present method showed good ruggedness when it was performed using different analysts and on different instruments of the same make. The results of the ruggedness study for axitinib were within the acceptance limit. The data are shown in Table X. The precision and accuracy values for different columns with different analysts ranged from $4.21 \%$ to $10.68 \%$ and $94.85 \%$ to $110.60 \%$.

\section{Stability studies}

The stability of the analytes was studied by keeping replicates of low, middle and high quality control samples at Zero hours, Long batch, LT at $-28{ }^{\circ} \mathrm{C}$ and LT at -80 ${ }^{\circ} \mathrm{C}$. The results of LQC, MQC and HQC were found to be greater than $95 \%$, which is within the acceptance limit. This shows that the analyte was stable for the entire analytical period. The results are compiled in Table XI.

\section{SUMMARY AND CONCLUSION}

The proposed HPLC method for the determination of axitinib in rabbit plasma by using a UV detector is simple, accurate and utilizes protein precipitation with acetonitrile. The isocratic elution, short elution time of less than $10 \mathrm{~min}$ and UV detection makes the method cost effective. The results obtained prove that the method was 
TABLE VIII - Recovery of analyte

\begin{tabular}{|c|c|c|c|c|c|c|}
\hline \multirow[t]{2}{*}{ Sample } & \multicolumn{2}{|c|}{ HQC } & \multicolumn{2}{|c|}{ MQC } & \multicolumn{2}{|c|}{ LQC } \\
\hline & $\begin{array}{c}\text { Un extracted } \\
\text { Response }\end{array}$ & $\begin{array}{l}\text { Extracted } \\
\text { Response }\end{array}$ & $\begin{array}{c}\text { Un extracted } \\
\text { Response }\end{array}$ & $\begin{array}{l}\text { Extracted } \\
\text { Response }\end{array}$ & $\begin{array}{l}\text { Un extracted } \\
\text { Response }\end{array}$ & $\begin{array}{l}\text { Extracted } \\
\text { Response }\end{array}$ \\
\hline Mean $(n=6)$ & 70977.5 & 35805.3 & 42677.7 & 24495.7 & 1660.8 & 966.8 \\
\hline SD & 812.76 & 254.91 & 545.80 & 192.05 & 31.61 & 16.71 \\
\hline$\% \mathrm{CV}$ & 1.15 & 0.71 & 1.28 & 0.78 & 1.90 & 1.73 \\
\hline $\begin{array}{l}\% \text { Mean } \\
\text { Recovery }\end{array}$ & \multicolumn{2}{|c|}{50.45} & \multicolumn{2}{|c|}{57.40} & \multicolumn{2}{|c|}{58.21} \\
\hline $\begin{array}{l}\text { Overall \% Mean } \\
\text { Recovery }\end{array}$ & \multicolumn{6}{|c|}{55.352} \\
\hline Overall SD & \multicolumn{6}{|c|}{4.2685} \\
\hline Overall \% CV & \multicolumn{6}{|c|}{7.71} \\
\hline
\end{tabular}

TABLE IX - Recovery of internal standard

\begin{tabular}{lcc}
\hline S. No. & Unextracted Area Ratio & Extracted Area Ratio \\
\hline Mean $(\mathrm{n}=6)$ & 35931.7 & 26755.2 \\
SD & 150.63 & 289.04 \\
$\% \mathrm{CV}$ & 0.42 & 1.08 \\
\hline \% Mean Recovery & & \\
\hline
\end{tabular}

TABLE X - Ruggedness data

\begin{tabular}{|c|c|c|c|c|}
\hline \multirow[t]{5}{*}{ P\&A ID } & HQC & MQC & LQC & LLOQ \\
\hline & \multicolumn{4}{|c|}{ Nominal Concentration $(\mu \mathrm{g} / \mathrm{mL})$} \\
\hline & 0.150 & 0.080 & 0.020 & 0.002 \\
\hline & \multicolumn{4}{|c|}{ Nominal Concentration Range $(\mu \mathrm{g} / \mathrm{mL})$} \\
\hline & $(0.128-0.173)$ & $(0.068-0.092)$ & $(0.017-0.023)$ & $(0.002-0.002)$ \\
\hline & \multicolumn{4}{|c|}{ Calculated Concentration $(\mu \mathrm{g} / \mathrm{mL})$} \\
\hline \multicolumn{5}{|c|}{ Different Column } \\
\hline Mean $(n=6)$ & 0.1547 & 0.0784 & 0.0190 & 0.0022 \\
\hline SD & 0.01651 & 0.00565 & 0.00134 & 0.00009 \\
\hline$\% \mathrm{CV}$ & 10.68 & 7.20 & 7.07 & 4.12 \\
\hline$\%$ Mean Accuracy & 103.11 & 97.96 & 94.85 & 109.74 \\
\hline \multicolumn{5}{|c|}{ Different Analyst } \\
\hline Mean $(n=6)$ & 0.1528 & 0.0821 & 0.0205 & 0.0022 \\
\hline SD & 0.00924 & 0.00619 & 0.00149 & 0.00010 \\
\hline$\% \mathrm{CV}$ & 6.05 & 7.55 & 7.25 & 4.50 \\
\hline$\%$ Mean Accuracy & 101.89 & 102.61 & 102.60 & 110.60 \\
\hline
\end{tabular}

accurate and reproducible. In summary, the developed chromatographic method may be used for the routine bioanalysis of axitinib.

\section{ACKNOWLEDGEMENT}

The authors are thankful to V.V. Institute of 
TABLE XI - Stability data

\begin{tabular}{|c|c|c|c|}
\hline Sample & $\begin{array}{c}\text { Nominal Concentration } \\
\qquad(\mu \mathrm{g} / \mathrm{mL})\end{array}$ & $\begin{array}{c}\text { Mean Calculated Concentration } \\
\qquad \begin{array}{c}(\mu \mathrm{g} / \mathrm{mL}) \pm \mathrm{SD} \\
(\mathrm{n}=6)\end{array}\end{array}$ & $\% \mathrm{CV}$ \\
\hline \multicolumn{4}{|c|}{ Stability on day zero } \\
\hline $\mathrm{HQC}$ & 0.150 & $0.1465 \pm 0.157$ & 10.69 \\
\hline LQC & 0.020 & $0.0196 \pm 0.002$ & 8.05 \\
\hline \multicolumn{4}{|c|}{ Long batch at $-28^{\circ} \mathrm{C}$} \\
\hline HQC & 0.150 & $0.1536 \pm 0.014$ & 8.91 \\
\hline LQC & 0.020 & $0.0205 \pm 0.002$ & 9.81 \\
\hline \multicolumn{4}{|c|}{ Long batch at $-80^{\circ} \mathrm{C}$} \\
\hline HQC & 0.150 & $0.1504 \pm 0.012$ & 8.07 \\
\hline LQC & 0.020 & $0.0189 \pm 0.001$ & 7.29 \\
\hline
\end{tabular}

Pharmaceutical Sciences, Gudlavalleru for providing facilities to carry out this work.

\section{REFERENCES}

Alanazi F.K, Mowafy H.A, Magharaby G.M.E. Development and validation of an HPLC-UV method for the quantification of carbamazepine in rabbit plasma. Saudi Pharm J. 2012;20:29-34.

Cohen E, Rosen L, Vokes E, Kies M, Forastiere A, Worden F, et al. Axitinib is an active treatment for all histologic subtypes of advanced thyroid cancer: results from a phase II study. J Clin Oncol. 2008;26(29):4708-4713.

Food and Drug Administration. FDA. Guidance for industry, bioanalytical method validation. Silver Spring: FDA, 2001.

Garrett M, Poland B, Brennan M, Hee B, Pithavala YK, Amantea MA. Population pharmacokinetic analysis of axitinib in healthy volunteers. Brit J Clin Pharmacol. 2014; 77(3):480-492.

Inlyta: axitinib tablet, film coated. New York: Pfizer Laboratories; 2014. [accessed May 19, 2016] Avaiable from: http://labeling. pfizer.com/ShowLabeling.aspx?id=759

Likar MD, Cheng G, Mahajan N, Zhang Z. Rapid identification and absence of drug tests for AG-013736 in $1 \mathrm{mg}$ Axitinib tablets by ion mobility spectrometry and DART ${ }^{\mathrm{TM}}$ mass spectrometry. J Pharm Biomed Anal. 2011;55(3):569-573.

Maring JG, Schouten L, Greijdanus B, Vries EGED, Uges DRA. A simple and sensitive fully validated HPLC-UV method for the determination of 5-fluorouracil and its metabolite 5,6-dihydrofluorouracil in plasma. Ther Drug Monitoring. 2005;27(1):25-30.
National Center for Biotechnology Information. NCBI. PubChem Compound Database;CID=6450551. [cited 2016 May 19]. Available from: https://pubchem.ncbi.nlm.nih.gov/ compound/6450551.

Phatak MS, Vaidya VV, Phatak HM. Development and validation of a rapid high performance liquid chromatography method for simultaneous quantification ofornidazole and miconazole from cream formulations. Int J Pharm Res Scholars.2014;3(4):191-197.

Probhash K, Sahu A, Noronha V, Joshi A, Desai S. Crizotinib: a comprehensive review. South Asian J Cancer. 2013;2(2):91-97.

Rote AR, Sonavame PR. Bioanalytical method development and validation for determination of metoprolol tartarate and hydrochlorothiazide using HPTLC in human plasma. Braz $J$ Pharm Sci. 2013;49(4):845-851.

Sagar SP, Bera VVRK, Panda N. Development and validation of a superior high performance liquid chromatographic method for quantification of axitinib in solid oral dosage form. $A m J$ Modern Chromatogr. 2016;3(1):33-43.

Sarada NC, Reddy BJC. Development and validation of stability indicating RP-HPLC method for the determination of axitinib in bulk and its pharmaceutical formulations. Der Pharmacia Lettre. 2016;8(11):97-106.

Sparidans RW, Iusuf D, Schinkel, AH, Schellens JHM, Beijnen $\mathrm{JH}$. Liquid chromatography-tandem mass spectrometric assay for the light sensitive tyrosine kinase inhibitor axitinib in human plasma. J Chromatogr B. 2009;877(32):4090-4096. 
Van Geel R, Beijnen J, Schellens J. Concise drug review: pazopanib and axitinib. Oncologist. 2012;17(8):1081-1089.

Wani TA, Iqbal M, Darwish IA, Khalil NY, Zargar S. Development and validation of sensitive UPLC-MS/MS based method for estimation of crizotinib in human plasma. Digest $J$ Nanomat Biostr. 2014;9(2):693-704.

Received for publication on $01^{\text {st }}$ October 2016 Accepted for publication on $25^{\text {th }}$ April 2017 